\title{
SISTEM PENDUKUNG KEPUTUSAN DENGAN MENERAPKAN LOGIKA FUZZY DALAM MENENTUKAN PRIORITAS CALON DEBITUR
}

\author{
Ahmadi Yuli Ananta ${ }^{1}$, Erfan Rohadi ${ }^{2}$, Dimas Wahyu Wibowo ${ }^{3}$ \\ ${ }^{1,2}$ Teknik Informatika, Politeknik Negeri malang \\ 1,2,3 ahmadi@poltek-malang.ac.id,erfanr@polinema.ac.id,dimas.w@polinema.ac.id
}

\begin{abstract}
Abstrak - Pinjaman dana tunai adalah fasilitas yang disediakan oleh PT. NSC Finance untuk konsumen melakukan pinjaman dengan jaminan BPKB Motor. Proses pengolahan pinjaman dana tunai di proses bagian marketing, survey, dan administrasi. Data yang dikelola adalah berkas pengajuan, surat perjanjian pinjaman dana tunai, motor di asuransikan, hasil survey, jumlah pinjaman, angsuran pinjaman dan pembayaran angsuran. Sedangkan laporan yang di proses dalam pinjaman dana tunai adalah laporan berkas pengajuan, laporan angsuran konsumen, isi perjanjian pembayaran dan laporan motor yang digunakan. Proses input data dilakukan oleh admin atau Credit Marketing Suvervisor (CMS). Jika salah satu syarat tidak terpenuhi maka secara otomatis sistem akan menolak penga- juan pinjaman dana, sehingga dapat meng ganggu pemasukan perusahaan.Sehingga diperlukan sistem pendukung keputusan yang dapat membantu perusahaan dalam mengambil keputusan. Dengan menggunakan Sistem Pendukung Keputusan menggunakan fuzzy diharapkan dapat mempermudahkan peru sahaan dalam menentukan prioritas pinjaman dana kepada Nasabah.
\end{abstract}

Kata kunci : NSC, Sistem Pendukung Keputusan, Fuzzy.

\section{PENDAHULUAN}

PT. Nusa Surya Ciptadana merupakan lembaga pembiayaan kendaraaan bermotor yang merupakan bagian dari Nusantara Group didirikan pada tahun 2000 serta disahkan oleh Menteri Kehakiman Republik Indonesia pada 27 April 2001. PT. Nusa Surya Ciptadana memiliki cabang di 93 lokasi yang tersebar di 28 propinsi di Indonesia. NSC Finance mulai Agustus 2004 membiayai mayoritas kredit di authorized dealer sepeda motor Honda PT. Nusantara Sakti dan PT. Nusantara Surya Sakti yang merupakan "Sister Company" yang mempunyai cabang di 91 kota yang tersebar di seluruh wilayah Indonesia. NSC Finance mempunyai pangsa pasar sendiri yang 'captive' karena tergabung dalam group dealer sepeda motor sehingga dengan layanan satu atap ini akan mewujudkan konsep Nusantara Group berupa 3T yaitu Tercepat, Termudah, dan Terpercaya dalam bidang
Kepemilikan Kendaraan Bermotor. NSC Finance didukung oleh direksi PT. Nusantara Sakti dan PT. Nusantara Surya Sakti yang berpengalaman dalam penjualan sepeda motor sejak tahun 1962 dan pembiayaan sepeda motor sejak tahun 1984.

Salah satu cabang NSC Finance terdapat di malang beralamat jln.Soekarno Hatta no.D510 Malang. Untuk kantor NSC Finance terdapat pada lantai 2, sedangkan pada lantai 1 merupakan kantor dari NSS dealer. Sehingga konsumen yang akan meminjam dana tunai dapat menuju kantor NSC pada lantai 2. Untuk Proses pinjaman dana dilakukan survey terlebih dahulu ke rumah konsumen dan melakukan cek lingkungan untuk mengetahui informasi calon debitur. Setelah proses cek lingkungan selesai maka data dari surveyor akan diserahkan ke admin untuk diinput berdasarkan hasil dari cek lingkungan surveyor. Untuk selama ini hasil keputusan diterima atau tidaknya calon debitur untuk mengajukan pinjaman dana hanya berdasarkan lapangan. Sistem hanya untuk memasukkan data tanpa adanya sistem pendukung keputusan untuk membantu perusahaan dalam menentukan calon debitur.

Sehingga diperlukan sistem pendukung keputusan yang dapat membantu perusahaan dalam mengambil keputusan. Dengan menggunakan sistem pendukung keputusan dengan logika fuzzy diharapkan dapat membantu perusahaan dalam menentukan prioritas pinjaman dana kepada calon nasabah.

\section{Tinjauan Pustaka}

\section{A. Sistem Pendukung Keputusan (SPK)}

Menurut Turban Sistem Pendukung Keputusan (SPK) atau Decision Support System (DSS) adalah sebuah sistem yang dapat memecahkan masalah dengan kondisi semi terstruktur dan tak terstruktur. SPK dapat membantu memberikan penilaian terhadap alternatif dalam pengambilan keputusan. Proses pengambilan keputusan terdiri dari tiga fase proses, yaitu:

- Fase intelligence atau studi kelayakan, dalam tahap ini dilakukan proses identifikasi masalah

- Fase design atau perancangan, dalam tahap ini memformulasikan model yang akan digunakan dan menentukan kriteria. 
- Fase choice atau pemilihan, dalam tahap ini didapatkan keluaran berupa solusi permasalahan.

Sistem Pendukung Keputusan terdiri dari tiga komponen utama yaitu:

- Subsistem data, merupakan komponen penyedia data yang diperlukan oleh sistem.

- Subsistem model, merupakan komponen yang mengubah data menjadi sebuah informasi yang berguna bagi sistem.

- Antarmuka pengguna, komponen ini berfungsi sebagai sarana interaksi antara user dengan sistem.

\section{B. Logika Fuzzy}

Logika Fuzzy pertama kali diperkenalkan oleh Prof. Lotfi A. Zadeh pada tahun 1965. Dasar logika fuzzy adalah teori himpunan fuzzy. Peranan derajat keanggotaan pada teori himpunan fuzzy sebagai penentu keberadaan elemen dalam suatu himpunan. Nilai keanggotaan atau derajat keanggotaan atau membership function menjadi ciri utama dari penalaran dengan logika fuzzy tersebut.

Fuzzy memiliki 3 bagian, yaitu fuzzifikasi, inferensi fuzzy, dan defuzzifikasi. Fuzzifikasi adalah proses untuk mengubah input sistem yang mempunyai nilai tegas menjadi variabel linguistik menggunakan fungsi keanggotaan yang disimpan dalam basis pengetahuan fuzzy. Inferensi fuzzy adalah proses untuk mengubah input fuzzy menjadi output fuzzy dengan cara mengikuti aturan-aturan (IF-THEN Rule) yang telah ditetapkan pada basis pengetahuan. Defuzzifikasi adalah proses mengubah output fuzzy yang diperoleh dari mesin inferensi menjadi nilai tegas menggunakan fungsi keanggotaan yang sesuai dengan saat dilakukan fuzzifikasi.

Ada beberapa fungsi keanggotaan himpunan fuzzy, antara lain fungsi keanggotaan linier, fungsi keanggotaan segitiga, dan fungsi keanggotaan trapesium

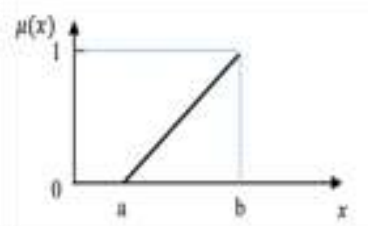

$$
\mu(x)\left\{\begin{array}{cc}
0 ; & j k a x \leq a \\
\frac{(x-a)}{(b-a)} ; & j i k a \leq x \leq b \\
1 ; & j i k a x \geq b
\end{array}\right.
$$

Gambar 1. Grafik fungsi keanggotaan himpunan representasi linear naik

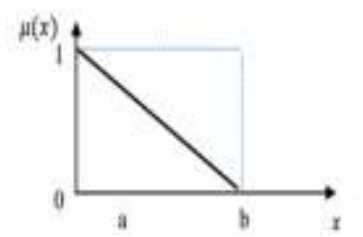

$$
\mu(x)\left\{\begin{array}{c}
\frac{(x-a)}{(b-a)} ; j i k a \leq x \leq b \\
0 ; \quad j k a x \geq b
\end{array}\right.
$$

Gambar 2. Grafik fungsi keanggotaan himpunan representasi linear turun

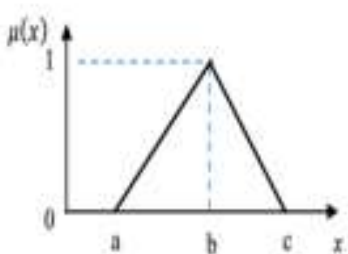

$\rho(x)\left\{\begin{array}{l}0 ; j i k a x \leq a \text { atau } x \leq c \\ \frac{(x-a)}{(b-a)} ; j i k a a<x \leq b \\ \frac{(c-x)}{(c-b)} ; j i k a b<x<c\end{array}\right.$

Gambar 3. Grafik fungsi keanggotaan himpunan representasi keanggotaan segitiga

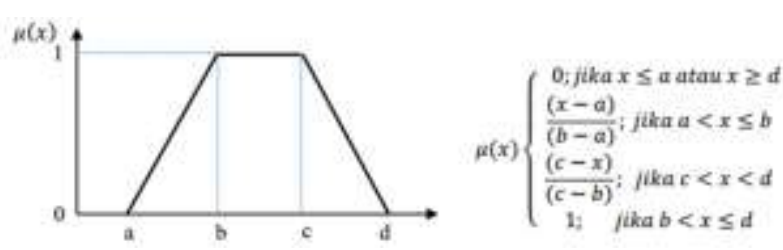

Gambar 4. Grafik fungsi keanggotaan himpunan fuzzy representasi keanggotaan trapesium

\section{Metode Penelitian}

\section{A. Desain Sistem}

\section{Analisa Kebutuhan Sistem}

Pada sistem ini, user dapat memasukan sendiri masukan data masing-masing parameter sesuai dengan range yang telah disediakan oleh sistem. Sistem akan memproses data input untuk dikelompokan sesuai fungsi keanggotaan dan rule yang telah ditentukan.

a. Kebutuhan Input

Kebutuhan input sistem terdiri dari: Status Rumah, penghasilan, dan Jenis_Pekerjaan.

b. Kebutuhan Output

Output sistem berupa rekomendasi nama calon debitur yang berhak mendapatkan pinjaman.

\section{Diagram Use Case}

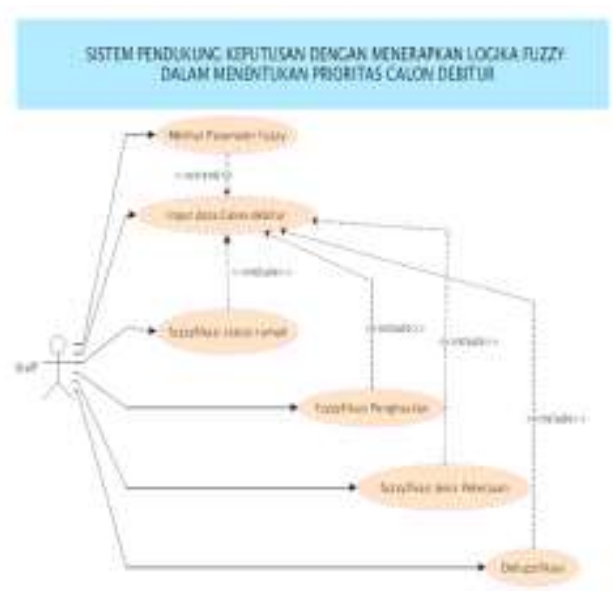

Gambar 5. Diagram Use Case 
Use case merupakan sebuah teknik yang digunakan dalam pengembangan sistem pendukung keputusan menggunakan metode fuzzy untuk mendapatkan kebutuhan fungsional dari sistem. Pada use case ini akan menjelaskan interaksi yang terjadi antara 'aktor'-'inisiator' dari sistem pendukung keputusan ini. Diagram Use Case untuk sistem pendukung keputusan menggunakan metode fuzzy seperti pada gambar 5 .

\section{Konsep Pembentukan Database}

Untuk konsep pembuatan database peneliti menggunakan satu tabel calon debitur dimana tabel ini berfungsi menampung data calon debitur. Pada tabel calon debitur terdapat 6 field antara lain Id, No_KTP, nama, Status_Rumah, Penghasilan, Jenis_Pekerjaan. Sedangkan untuk hasil perhitungan ditampilkan pada halaman web dan tidak disimpan pada database. Untuk struktur pembentukan database seperi pada gambar 6

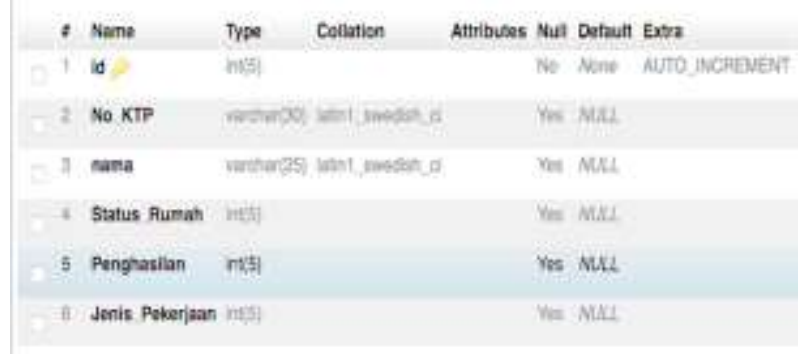

Gambar 6. Struktur Pembentukan Database

\section{Fungsi Derajat Keanggotaan}

Tabel 1. Data Calon Debitur

\begin{tabular}{|c|c|c|c|c|}
\hline No KTP & Nama & $\begin{array}{l}\text { Stat } \\
\text { us } \\
\text { Rum } \\
\text { ah }\end{array}$ & $\begin{array}{l}\text { Pengha } \\
\text { silan }\end{array}$ & $\begin{array}{c}\text { Jenis } \\
\text { Pekerj } \\
\text { aan }\end{array}$ \\
\hline $\begin{array}{c}35730160108 \\
\text { xxxx }\end{array}$ & $\begin{array}{l}\text { YENNY } \\
\text { MARSEL } \\
\text { A }\end{array}$ & 70 & 80 & 78 \\
\hline $\begin{array}{c}35730204109 \\
1 \text { xxxx }\end{array}$ & $\begin{array}{l}\text { FARIS } \\
\text { MARND } \\
\text { ANI }\end{array}$ & 60 & 60 & 70 \\
\hline $\begin{array}{c}35730524037 \\
4 \mathrm{xxxx}\end{array}$ & YASIN & 86 & 80 & 65 \\
\hline $\begin{array}{c}35730111027 \\
6 \times x x x x\end{array}$ & $\begin{array}{l}\text { ADI } \\
\text { SURYAN } \\
\text { TO }\end{array}$ & 90 & 88 & 65 \\
\hline $\begin{array}{c}35072207087 \\
3 \mathrm{xxxx}\end{array}$ & $\begin{array}{l}\text { SUGIANT } \\
\mathrm{O}\end{array}$ & 90 & 69 & 60 \\
\hline $\begin{array}{c}35790367019 \\
1 \times x x x\end{array}$ & $\begin{array}{l}\text { ENGKY } \\
\text { YANUAR } \\
\text { RISKA }\end{array}$ & 88 & 80 & 65 \\
\hline
\end{tabular}

\begin{tabular}{|c|c|c|c|c|}
\hline $\begin{array}{c}35730253019 \\
\text { 0xxxx }\end{array}$ & $\begin{array}{l}\text { RANI } \\
\text { SISKA }\end{array}$ & 77 & 77 & 77 \\
\hline & $\begin{array}{l}\text { BUDI } \\
\text { YUWON }\end{array}$ & & & \\
\hline $\begin{array}{l}35790116026 \\
9 x x x x\end{array}$ & $\begin{array}{l}\mathrm{O} \\
\text { ATASAG } \\
\text { AWA }\end{array}$ & 50 & 79 & 77 \\
\hline $\begin{array}{l}35071818057 \\
6 x x x x\end{array}$ & $\begin{array}{l}\text { AFANDI } \\
\text { KURNIA } \\
\text { WAN }\end{array}$ & 70 & 73 & 65 \\
\hline $\begin{array}{l}35730312127 \\
7 \mathrm{xxxx}\end{array}$ & $\begin{array}{l}\text { HENDIK } \\
\text { ISTIAWA } \\
\mathrm{N}\end{array}$ & 67 & 79 & 69 \\
\hline $\begin{array}{l}35072343047 \\
6 x x x x\end{array}$ & $\begin{array}{l}\text { CHUSNU } \\
\text { L } \\
\text { CHOTIM } \\
\text { AH }\end{array}$ & 72 & 69 & 60 \\
\hline $\begin{array}{l}35730423038 \\
20 x x x x\end{array}$ & $\begin{array}{l}\text { NUR } \\
\text { WAKIT }\end{array}$ & 80 & 70 & 67 \\
\hline $\begin{array}{l}35730371079 \\
1 \mathrm{xxxx}\end{array}$ & $\begin{array}{l}\text { NOVI } \\
\text { DWI } \\
\text { ELIA }\end{array}$ & 66 & 67 & 67 \\
\hline $\begin{array}{l}35790209047 \\
\text { 0xxxx }\end{array}$ & SURONO & 80 & 69 & 65 \\
\hline $\begin{array}{l}35072423038 \\
9 x x x x\end{array}$ & $\begin{array}{l}\text { M } \\
\text { ARIFIN }\end{array}$ & 67 & 66 & 67 \\
\hline
\end{tabular}

Pada fungsi derajat keanggotaan menggunakan fuzzy dibagi menjadi keanggotaan Status Rumah, penghasilan, dan jenis pekerjaan.

Tabel 2. Pengelompokan Status Rumah

\begin{tabular}{cccc}
\hline Variabel & $\begin{array}{c}\text { Himpunan } \\
\text { Fuzzy }\end{array}$ & kondisi & $\begin{array}{c}\text { Domain } \\
\text { Nilai }\end{array}$ \\
\hline Status & Kurang & $\begin{array}{c}\text { Dinas } \\
\text { atau } \\
\text { Kumah }\end{array}$ & $0-65$ \\
& & Kontrak & \\
& Cukup & Milik & $54-80$ \\
& & Keluarga & \\
& Tinggi & Milik & $65-100$ \\
& & Sendiri & \\
& & &
\end{tabular}

Fungsi keanggotaan untuk variabel Status Rumah terdiri dari tiga himpunan fuzzy yaitu Kurang, Cukup, dan Tinggi yang diambarkan dalam kurva segitiga sebagai 


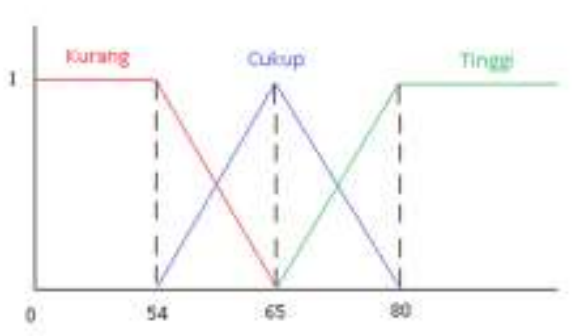

Gambar 7. Grafik Fungsi Keanggotaan Status Rumah

Fungsi keanggotaan:

$\mu$ Kurang $[\mathrm{x}]=\left\{\begin{aligned} 1, & x \leq 54 \\ \frac{65-x}{65-54}, & 54<x<65 \\ 0, & x \geq 65\end{aligned}\right.$

$\mu$ Cukup $[\mathrm{x}]= \begin{cases}0, & x \leq 54 \text { atau } x \geq 80 \\ \frac{x-65}{80-65}, & 54 \leq x \leq 65 \\ \frac{80-x}{80-65}, & 65 \leq x \leq 80\end{cases}$

$\mu$ Tinggi $[\mathrm{x}]=\left\{\begin{aligned} 0, & x \leq 65 \\ \frac{x-65}{80-65}, & 65 \leq x \leq 80 \\ 1, & x \geq 80\end{aligned}\right.$

Tabel 3. Pengelompokan Penghasilan

\begin{tabular}{lccc}
\hline \multicolumn{1}{c}{ Variabel } & $\begin{array}{c}\text { Himpunan } \\
\text { Fuzzy }\end{array}$ & $\begin{array}{c}\text { Range } \\
\text { Peghasilan } \\
\text { kotor orangtua } \\
(\mathrm{x})\end{array}$ & $\begin{array}{c}\text { Domain } \\
\text { Nilai }\end{array}$ \\
\hline $\begin{array}{l}\text { Penghasilan } \\
\text { kotor } \\
\text { orangtua }\end{array}$ & Kurang & $\mathrm{x}<1.000 .000$ & $0-65$ \\
& Cukup & $\begin{array}{c}1.000 .000<\mathrm{x} \\
<3.000 .000\end{array}$ & $54-80$ \\
& & $\mathrm{x}>3.000 .000$ & $65-100$ \\
\hline
\end{tabular}

Fungsi keanggotaan untuk variabel penghasilan terdiri dari tiga himpunan fuzzy yaitu Kurang, Cukup, dan Tinggi yang diambarkan dalam kurva segitiga sebagai berikut:

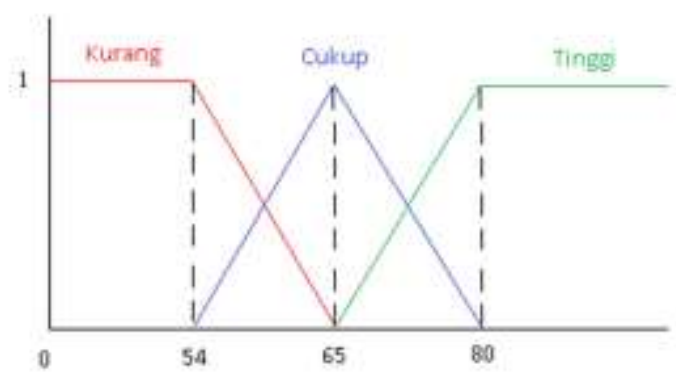

Gambar 8. Grafik Fungsi Keanggotaan Penghasilan
Fungsi keanggotaan:

$$
\begin{aligned}
& \mu \text { Kurang }[\mathrm{x}]=\left\{\begin{aligned}
1, & x \leq 54 \\
\frac{65-x}{65-54}, & 54<x<65 \\
0, & x \geq 65
\end{aligned}\right. \\
& \mu \text { Cukup }[\mathrm{x}]=\left\{\begin{aligned}
0, & x \leq 54 \text { atau } x \geq 80 \\
\frac{x-65}{80-65}, & 54 \leq x \leq 65 \\
\frac{80-x}{80-65}, & 65 \leq x \leq 80
\end{aligned}\right. \\
& \mu \text { Tinggi }[\mathrm{x}]=\left\{\begin{aligned}
0, & x \leq 65 \\
\frac{x-65}{80-65}, & 65 \leq x \leq 80 \\
1, & x \geq 80
\end{aligned}\right.
\end{aligned}
$$

Tabel 4 Pengelompokan Jenis Pekerjaan

\begin{tabular}{lccc}
\hline Variabel & $\begin{array}{c}\text { Himpunan } \\
\text { Fuzzy }\end{array}$ & $\begin{array}{c}\text { Jenis } \\
\text { Pekerjaan }\end{array}$ & $\begin{array}{c}\text { Domain } \\
\text { Nilai }\end{array}$ \\
\hline $\begin{array}{l}\text { Penghasilan } \\
\text { kotor } \\
\text { orangtua }\end{array}$ & Kurang & Lain-lain & $0-65$ \\
& Cukup & $\begin{array}{c}\text { Pegawai } \\
\text { Swasta }\end{array}$ & $54-80$ \\
& Tinggi & $\begin{array}{c}\text { Pegawai } \\
\text { Negeri }\end{array}$ & $65-100$ \\
& & . & \\
\hline
\end{tabular}

Fungsi keanggotaan untuk variabel prestasi non akademik terdiri dari tiga himpunan fuzzy yaitu lainlain:Wiraswasta, Pegawai Swasta, Pegawai Negeri yang diambarkan dalam kurva segitiga sebagai berikut:

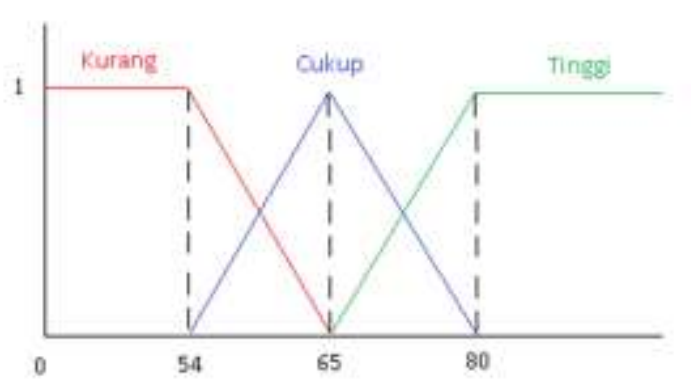

Gambar 9. Grafik Fungsi Keanggotaan Jenis Pekerjaan

Fungsi keanggotaan:

$$
\begin{aligned}
& \mu \text { Kurang }[\mathrm{x}]=\left\{\begin{aligned}
1, & x \leq 54 \\
\frac{65-x}{65-54}, & 54<x<65 \\
0, & x \geq 65
\end{aligned}\right. \\
& \mu \text { Cukup }[\mathrm{x}]=\left\{\begin{aligned}
0, & x \leq 54 \text { atau } x \geq 80 \\
\frac{x-65}{80-65}, & 54 \leq x \leq 65 \\
\frac{80-x}{80-65}, & 65 \leq x \leq 80
\end{aligned}\right.
\end{aligned}
$$


$\mu$ Tinggi $[\mathrm{x}]=\left\{\begin{aligned} 0, & x \leq 65 \\ \frac{x-65}{80-65}, & 65 \leq x \leq 80 \\ 1, & x \geq 80\end{aligned}\right.$

\section{Hasil Penelitian dan Pembahasan}

Bab ini merupakan hasil dan pembahasan sistem penerapan metode fuzzy dalam menentukan mahasiswa yang berhak menerima beasiswa. Proses melakukan identifikasi dilakukan dengan melaksanakan penelitian dan observasi pada sistem yang sedang berjalan. Hasil penelitian-penelitian tersebut dipergunakan untuk masukan ke dalam sistem yang akan dikembangkan.

\section{A. Antar Muka Pengguna}

Antar muka pengguna digunakan untuk memudahkan user dalam melakukan operasi perhitungan. Pada antar muka ini akan dijabarkan di beberapa bagian yang akan digunakan oleh $u$ ser.

\section{Halaman Utama}

Halaman utama adalah halaman awal yang diakses oleh user. Halaman ini terdiri dari judul penelitian dan pengertian dari Sistem Pendukung Keputusan. Selain itu pada halaman utama ini terdapat tombol toggle menu untuk menyembunyikan atau menampilkan menu pada sidebar. Pada side bar terdapat menu-menu yang dapat digunakan user atau untuk menampilkan hasil dari perhitungannya.

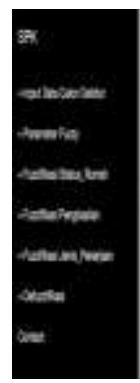

SISTEU PENOUKUNG KEPUTUSAN DEVGAN MERERAPKAN LOGIKA FUZZY DALAM MENENTUKAN PRIORTAS CALON DEBTIUR

Gambar 10. Antarmuka Halaman Utama

\section{Halaman Input Data Calon Debitur}

Pada halaman input data calon debitur user dapat memasukkan data berdasarkan No KTP, Nama, Status Rumah, Penghasilan, Jenis Pekerjaan. User memasukkan angka pada text box Status rumah, penghasilan dan jenis pekerjaan berdasarkan parameter fuzzy yang telah ditentukan diawal seperti pada gambar 11. Untuk memulai input data user dapat menekan tombol tambah data pada menu input data calon debitur pada sidebar seperti pada gambar 10

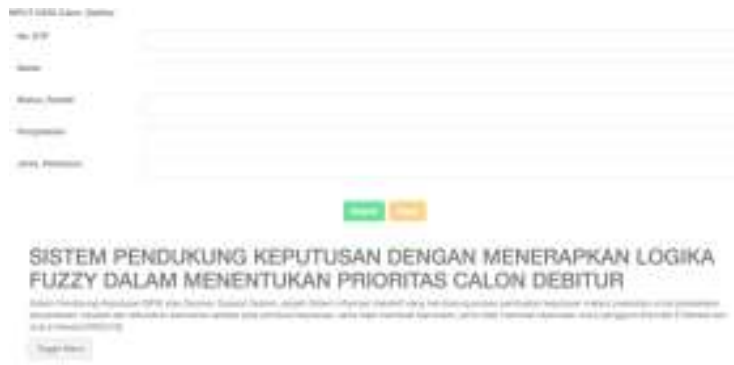

Gambar 11. Halaman Data Calon Debitur

\section{Halaman Data Calon Debitur}

Pada halaman ini digunakan user dapat melihat hasil inputan user dan user dapat juga melakukan proses edit dan delete data.

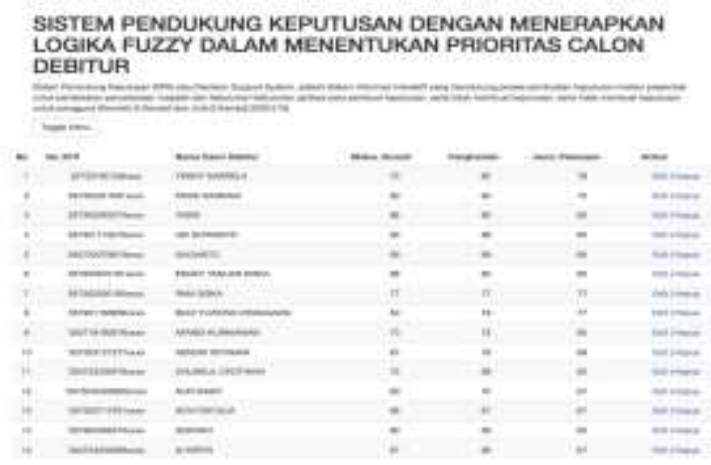

Gambar 12. Halaman Data Calon Debitur

\section{Halaman Parameter Fuzzy}

Pada halaman parameter fuzzy user dapat mengetahui parameter-paramater yang digunakan. Pada saat proses input data user harus mengacu pada parameter-paramater yang telah ditentukan pada halaman parameter fuzzy sehingga hasil dari proses perhitungan dapat berjalan dengan baik dan benar. Halaman ini sangat perlu dikarenakan agar user dapat melihat kembali parameter-paramater dan kententuan yang berlaku agar tidak terjadi kesalahan perhitungan. Adapun isi dari tabel dari input fuzzy ini adalah variabel yang terdiri dari 2 kolom yaitu nama dan notasi, himpunan fuzzy nama dan notasi, kondisi dan domain.

Untuk variabel nama terdapat 3 baris yaitu status rumah, penghasilan dan jenis pekerjaan. Pada baris status rumah terdapat 3 baris yang terdiri kurang, cukup dan tinggi begitu juga dengan penghasilan dan jenis pekerjaan. Sedangkan pada kolom kondisi adalah menjelaskan kondisi dari masing-masing baris dari himpunan input fuzzy seperti pada variabel status rumah dengan notasi A dan pada kolom himpunan input fuzzy dengan baris nama kurang notasi $\mathrm{K}$ maka kondisinya adalah Dinas atau kontrak. Sedangkan kolom terakhir adalah domain, kolom ini sebagai acuan user untuk menentukan inputan pada text box status rumah, penghasilan dan jenis pekerjaan pada proses input data. 


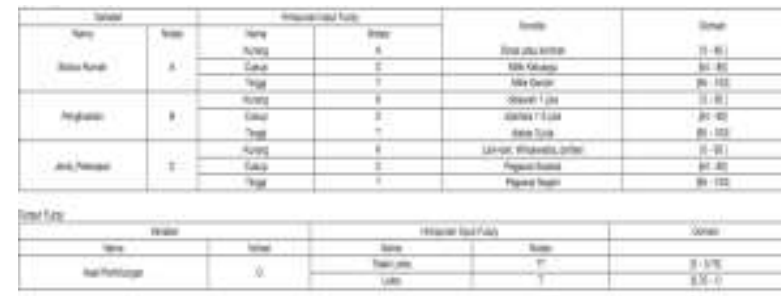

SISTEM PENDUKUNG KEPUTUSAN DENGAN MENERAPKAN LOGIKA FUZZY DALAM MENENTUKAN PRIORITAS CALON DEBITUR

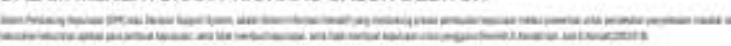

Gambar 13. Halaman Parameter Fuzzy

\section{Halaman Fuzzifikasi Status Rumah}

Halaman fuzzifikasi status rumah adalah halaman hasil perhitungan dari proses fuzzy berdasarkan inputan dari user berupa status rumah. Pada halaman ini user dapat melihat nama calon debitur, status rumah yang merupakan inputan awal dari user, derajat keanggotaan yang terdiri dari kurang, cukup dan tinggi dan terdapat kolom terakhir adalah drajat anggota. Untuk kolom terakhir derajat anggota adalah hasil dari perhitungan fuzzy berdasarkan status rumah

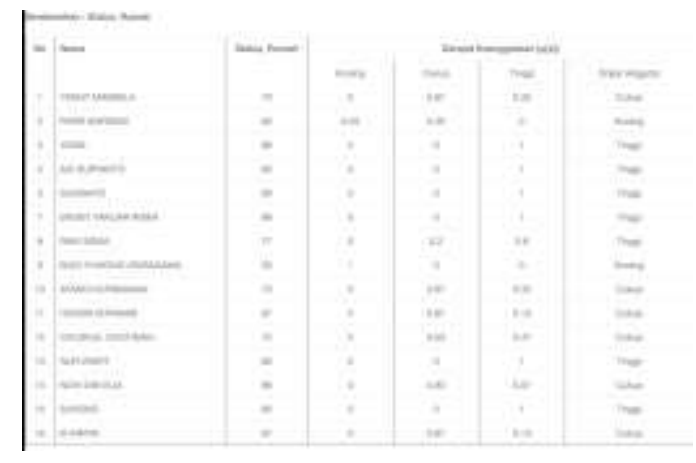

Gambar 14. Halaman Fuzzifikasi Status Rumah

\section{Halaman Fuzzifikasi Status Penghasilan}

Halaman fuzzifikasi status pengahasilan adalah halaman hasil perhitungan dari proses fuzzy berdasarkan inputan dari user berupa status penghasilan. Pada halaman ini user dapat melihat nama calon debitur, status penghasilan yang merupakan inputan awal dari user, derajat keanggotaan yang terdiri dari kurang, cukup dan tinggi dan terdapat kolom terakhir adalah drajat anggota. Untuk kolom terakhir derajat anggota adalah hasil dari perhitungan fuzzy berdasarkan status penghasilan.

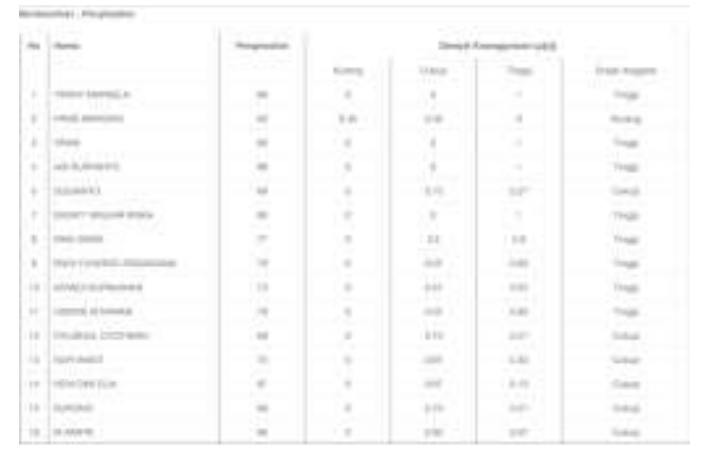

Gambar 15. Halaman Fuzzifikasi Penghasilan

\section{Halaman Fuzifikasi Jenis Pekerjaan}

Halaman fuzzifikasi status jenis pekerjaan adalah halaman hasil perhitungan dari proses fuzzy berdasarkan inputan dari user berupa status jenis pekerjaan. Pada halaman ini user dapat melihat nama calon debitur, status jenis pekerjaan yang merupakan inputan awal dari user, derajat keanggotaan yang terdiri dari kurang, cukup dan tinggi dan terdapat kolom terakhir adalah drajat anggota. Untuk kolom terakhir derajat anggota adalah hasil dari perhitungan fuzzy berdasarkan status jenis pekerjaan

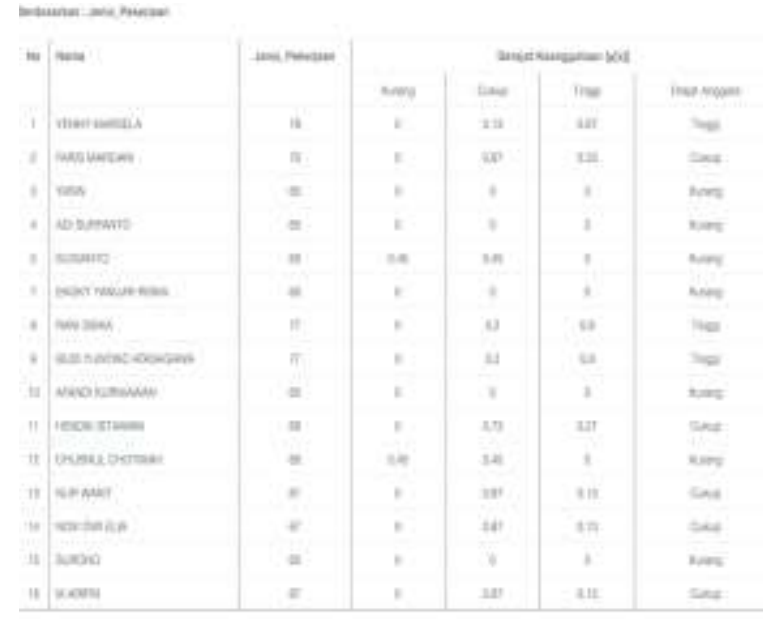

Gambar 16. Halaman Fuzzifikasi Jenis Pekerjaan

\section{Halaman Defuzzifikasi}

Halaman defuzzifikasi ini adalah merupakan kesimpulan dari perhitungan fuzzy berdasarkan status rumah, penghasilan dan jenis pekerjaan. User dapat melihat kesimpulan dari perhitungan pada kolom keterangan. Pada kolom keterangan terdapat keterangan calon debitur itu lolos atau tidak lolos. Lolos dan tidak lolosnya calon debitur yang akan melakukan proses peminjaman dana berdasarkan total kemampuan dimana total kemampuan ini adalah hasil total perhitungan status rumah, penghasilan dan jenis pekerjaan yang telah diinputkan oleh user pada halaman input data calon debitur. 


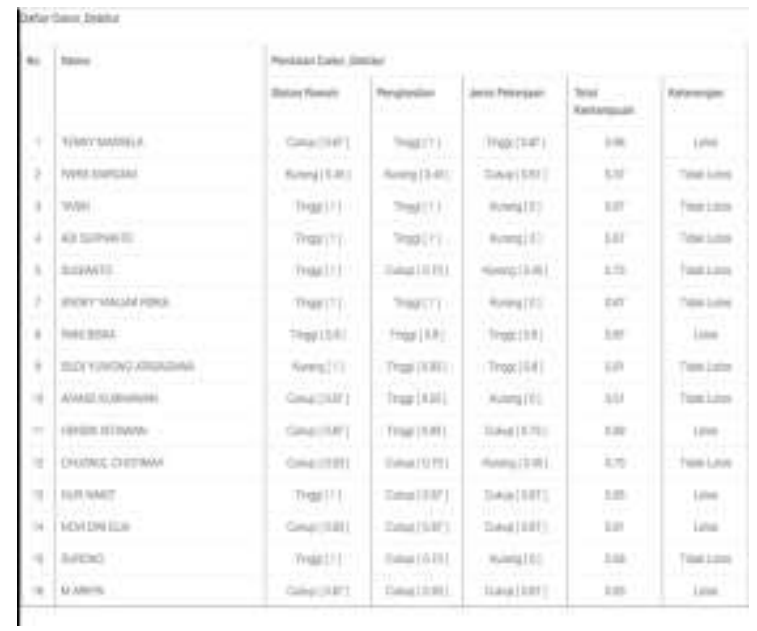

Gambar 17. Halaman DeFuzzifikasi

\section{B. Pengujian}

Untuk proses pengujian peneliti menggunakan 15 sampel data yang didapat dari PT.NSC yang nantinya diinputkan pada sistem atau aplikasi yang telah dibuat. Untuk 15 data sampel yang telah diambil ini telah diinput pada sistem PT.NSC dan kondisinya telah diterima atau lolos semua. Sedangkan untuk penentuan point peneliti meminta bantuan bagian lapangan dalam hal ini adalah surveyor berdasarkan kondisi di lapangan.

\begin{tabular}{|c|c|c|c|c|c|c|}
\hline 80 & was & masere & he ronus & Nis tesceuth & & ht \\
\hline 2xocus & Exthest & $x$ & 791 & 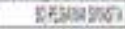 & is & 1 \\
\hline 2002 & ingerwis & ax & होत & 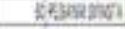 & wa & $\pi$ \\
\hline 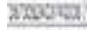 & & 4 & ty & S.M. & arvos & z \\
\hline 2xtasy: & CSAn: & in & rst & resw & DS & E \\
\hline EDWW & 8vato & M & St & 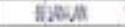 & 的 & e \\
\hline 30: & कoveres: & 幽 & Ex & 5.enter & 51 & 8 \\
\hline $5 \operatorname{ser} 4$ & Wis & $x$ & $\pi 25$ & 175mente? & Isx & 7 \\
\hline Frrisea: & orescivose & & XXI & $\pi \pi$ & $x$ & 7 \\
\hline ExpD & hoceate & $x$ & $7 y$ & tiwedit & क्रा & t \\
\hline 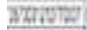 & c6rstan & a & Fin & 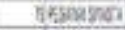 & $a$ & e \\
\hline YDWAEA & $60.400 \mathrm{~B}$ & $x$ & Fit & 5.8.th & Alesen & t \\
\hline artoras & uts & 15 & Sy & roguras & 2 & F \\
\hline atrives: & contion & II & EU & Ex SCUEN? & & f \\
\hline 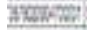 & $\mathrm{wOC}$ & Is & Dit & T.e. & ins & i \\
\hline whont & Yyan & 18 & ryt & X8301895: & गี! & 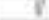 \\
\hline
\end{tabular}

Gambar 18. Sampel data

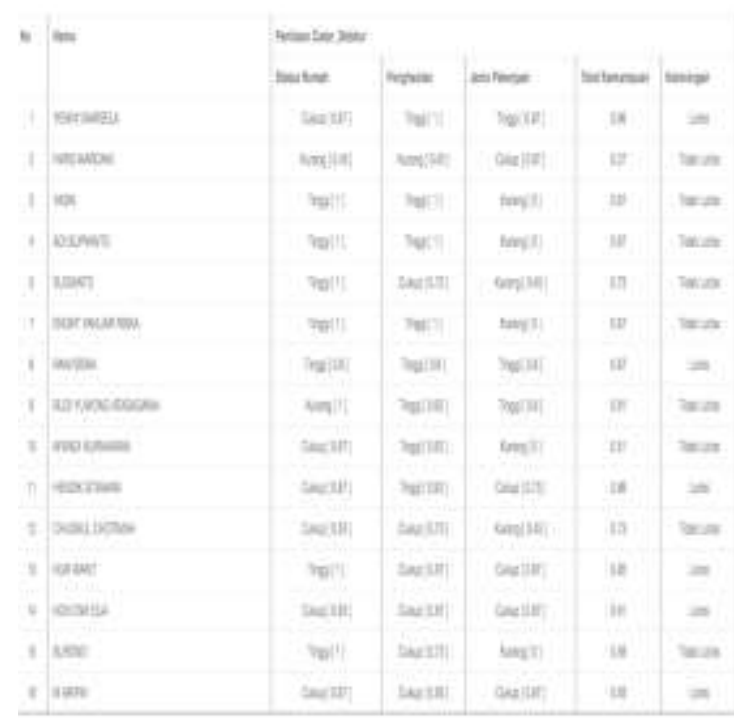

Gambar 19. Hasil Perhitungan Sistem

Setelah data telah dimasukkan ke dalam sistem tidak semua dapat lolos pada sistem hal ini dikarenakan pada aplikasi peneliti menentukan jika salah satu derajat keanggotaan pada calon debitur terdapat yang kurang maka sistem akan menolak atau dalam hal ini calon debitur tersebut tidak dapat lolos. Dari 15 data yang telah diterima oleh PT.NSC hanya 6 calon debitur saja yang lolos menurut sistem antara lain Yenny, Rani, Hendik, Nur, Novi, dan M.Arifin.

\section{KESIMPULAN DAN SARAN}

\section{A. Kesimpulan}

Dari hasil penelitian yang dilakukan maka dapat diambil kesimpulan sebagai berikut logika fuzzy dapat diterapkan untuk menentukan calon debitur yang berhak mendapatkan pinjaman dana dengan menggunakan nilai kriteria-kriteria sebagai data input fuzzy. Dengan logika fuzzy proses penyeleksian menjadi lebih adil dan akurat dengan memperhatikan nilai yang proporsional bagi setiap kriteria perekrutannya. Logika fuzzy dapat dijadikan sebagai alat bantu pendukung keputusan dalam melakukan proses seleksi penerimaan pinjaman dana tunai.

\section{B. Saran}

1. Dapat dilakukan penambahan variabel.

2. Dalam perhitungan solusi dengan menggunakan model fuzzy, dapat memperbanyak pilihan kriteria yang diajukan sistem yang bersifat dinamik, yang terdiri dari variabel input fuzzy dan variabel input non fuzzy.

\section{Daftar Pustaka}

[1] Turban, Efraim, 2005, Sistem Pendukung Keputusan dan Sistem Cerdas, Andi, Yogyakarta.

[2] Kusumadewi, Sri. 2007. Sistem Fuzzy Untuk Klasifikasi Indikator Kesehatan Daerah. Yogyakarta. ISSN: 978-979-96964-5-8. 
[3] Kusumadewi, Sri \& Hari Purnomo. 2010. Aplikasi Logika Fuzzy Untuk Pendukung keputusan Edisi Kedua. Yogyakarta: Graha Ilmu.

[4] Kusrini, Konsep dan Aplikasi Sistem Pendukung keputusan. Yogyakarta : Penerbit ANDI, 2007.

[5] Cristiono, Denny, 2005, Aplikasi Pendukung Keputusan Dengan Menggunakan Logika Fuzzy (studi kasus Pemilihan Handphone Berdasarkan Kebutuhan Konsumen), Salatiga, Fakultas Teknologi Informasi, Universitas Kristen Satya Wacana.
[6] Yudanto, A.Y, Apriyadi, M dan Sanjaya, K. Optimalisasi Lampu Lalu Lintas dengan Fuzzy Logic, ULTIMATICS, Vol V, No.2 | Desember 2013

[7] Wibowo, D.W , Amalia, E.L Sistem Pendukung Keputusan dalam menentukan beasiswa berprestasi Menggunakan Metode Fuzzy(Studi Kasus:Instansi XYZ) ANTIVIRUS, Vol 11 No 1 Mei 2017 